\title{
Descriptions of Rhodopseudomonas parapalustris sp. nov., Rhodopseudomonas harwoodiae sp. nov. and Rhodopseudomonas pseudopalustris sp. nov., and emended description of Rhodopseudomonas palustris
}

Correspondence

Ch. Sasikala

sasi449@yahoo.ie or r449@sify.com

\author{
V. Venkata Ramana, ${ }^{1}$ S. Kalyana Chakravarthy, ${ }^{2}$ P. Shalem Raj, ${ }^{1}$ \\ B. Vinay Kumar, ${ }^{1}$ E. Shobha, ${ }^{2}$ E. V. V. Ramaprasad, ${ }^{1}$ Ch. Sasikala ${ }^{1}$ \\ and Ch. V. Ramana ${ }^{1}$
}
${ }^{1}$ Bacterial Discovery Laboratory, Centre for Environment, IST, JNT University Hyderabad, Kukatpally, Hyderabad 500 085, India
${ }^{2}$ Department of Plant Sciences, School of Life Sciences, University of Hyderabad, PO Central University, Hyderabad 500 046, India

Abbreviations: $\mathrm{AH}$, aminohopanoid; $\mathrm{AL}$, aminolipid; $\mathrm{BChl}$, bacteriochlorophyll; DPG, diphosphatidylglycerol; PABA, para-aminobenzoic acid; $P C$, phosphatidylcholine; $P E$, phosphatidylethanolamine; PG, phosphatidylglycerol; PL, phospholipid.

The GenBank/EMBL/DDBJ accession numbers for the 16S rRNA gene sequences of strains JA310 ${ }^{\top}, J A 531^{\top}, J A 447$ and JA490 are AM947938, FN813512, FN543491 and FN813513, respectively.

Two supplementary figures and additional supplementary data are available with the online version of this paper.
Ever since the first description of the genus Rhodopseudomonas (Czurda \& Maresch, 1937), classification of members of this genus has been subject to significant changes including reclassification of species (Imhoff et al., 1984; Hiraishi \& Ueda, 1994; Hiraishi, 1997). Currently, there are only three species with validly published names remaining in this genus (http://www.bacterio.cict.fr/qr/rhodo pseudomonas.html): Rhodopseudomonas palustris ATCC $17001^{\mathrm{T}}$, Rhodopseudomonas rhenobacensis DSM $12706^{\mathrm{T}}$ and 
Rhodopseudomonas faecalis JCM $11668^{\mathrm{T}}$. In this study, we propose the description of two novel species, Rhodopseudomonas harwoodiae sp. nov. (with two additional strains) and Rhodopseudomonas parapalustris sp. nov., to accommodate four novel isolates from different geographical regions of India. We also propose that strain DSM $123^{\mathrm{T}}$ (listed as a type strain of $R$. palustris) represents a novel species, Rhodopseudomonas pseudopalustris sp. nov., since this strain showed genotypic and phenotypic differences (Okamura et al., 2009; this study) to R. palustris ATCC $17001^{\mathrm{T}}$ and all other members of the genus Rhodopseudomonas.

Strain JA310 ${ }^{\mathrm{T}}$ was isolated from a soil sample collected below salt crystals near Pangong Lake, Jammu and Kashmir, India on 22 May 2006 (GPS position $33^{\circ} 43^{\prime}$ $\left.04.59^{\prime \prime} \mathrm{N} 78^{\circ} 53^{\prime} 48.48^{\prime \prime} \mathrm{E}\right)$. Strain JA531 ${ }^{\mathrm{T}}$ was isolated from sediment of a saltpan at Kalambakam, Tamil Nadu, India (GPS position $12^{\circ} 45.464^{\prime} \mathrm{N} 86^{\circ} 12.728^{\prime} \mathrm{E}$ ). Strains JA447 and JA490 were isolated from a freshwater pond near Jamnagar, Gujarat, India (GPS position $22^{\circ} 23^{\prime} 27.86^{\prime \prime} \mathrm{N}$ $69^{\circ} 55^{\prime} 01.97^{\prime \prime} \mathrm{E}$ ) and sediment of a freshwater canal at Venkatapuram, Karimnagar District, India (GPS position $18^{\circ} 38^{\prime} 30.79^{\prime \prime} \mathrm{N} 79^{\circ} 27^{\prime} 10.63^{\prime \prime} \mathrm{E}$ ), respectively. All strains were isolated from enrichments obtained in a previously described medium (Lakshmi et al., 2009) with pyruvate $(25 \mathrm{mM})$ and ammonium chloride $(7 \mathrm{mM})$ as carbon and nitrogen sources, respectively, in $50 \mathrm{ml}$ fully filled screwcapped bottles incubated at a light intensity of $2500 \mathrm{~lx}$ and $30 \pm 2{ }^{\circ} \mathrm{C}$ for 7 days under anaerobic conditions. Cultures were purified by repeated streaking on agar slants (Srinivas et al., 2007; Lakshmi et al., 2009) and were maintained in pure culture under refrigeration at $4{ }^{\circ} \mathrm{C}$ and preserved as lyophilized vials. $R$. palustris DSM $123^{\mathrm{T}}, R$. palustris ATCC $17001^{\mathrm{T}}, R$. faecalis JCM $11668^{\mathrm{T}}$ and $R$. rhenobacensis DSM $12706^{\mathrm{T}}$ were obtained from the respective culture collection centres and used for comparative studies in our laboratory as recommended by Tindall et al. (2010).

Cell morphology (cell shape, cell division, cell size, flagella and visible internal or external structures) was observed by phase-contrast microscopy (Olympus $\mathrm{BH}-2$ ) and transmission electron microscopy (Hitachi H-7500 model). For transmission electron microscopic examination, cells were subjected to negative staining with phosphotungstic acid and grids were examined under a Hitachi H-7500 electron microscope. Motility was examined by the hanging drop method. Growth at various $\mathrm{NaCl}$ concentrations $[0-10 \%$ $(\mathrm{w} / \mathrm{v})$ at intervals of $0.5 \%], \mathrm{pH}(\mathrm{pH} 5.0-10.0$, at intervals of $0.5 \mathrm{pH}$ units) and temperatures $\left(5-45^{\circ} \mathrm{C}\right.$, at intervals of $5{ }^{\circ} \mathrm{C}$ ) was investigated in the medium described above. Utilization of organic compounds as carbon sources/ electron donors under photoheterotrophic growth was tested in the above medium containing the specific organic compound $(0.35 \%, \mathrm{w} / \mathrm{v})$ in the presence of yeast extract $(0.01 \%, \mathrm{w} / \mathrm{v}) . \mathrm{Na}_{2} \mathrm{~S} .9 \mathrm{H}_{2} \mathrm{O}(0.1,0.5,1.0 \mathrm{mM})$ and $1 \mathrm{mM}$ each of $\mathrm{MgSO}_{4}, \mathrm{Na}_{2} \mathrm{~S}_{2} \mathrm{O}_{3}, \mathrm{~S}^{0}, \mathrm{SO}_{3}^{2-}$, cysteine and thioglycolate were tested for utilization as sulfur source. Nitrogen source utilization was tested by replacing ammonium chloride with urea, nitrate, nitrite, glutamate and glutamine at $0.06 \%(\mathrm{w} / \mathrm{v})$. Vitamin requirement was tested by replacing yeast extract with different vitamins [vitamin $B_{12}$, biotin, niacin, para-aminobenzoic acid (PABA), pantothenate, pyridoxal phosphate, riboflavin, thiamine and a mixture of all the above vitamins $(0.02 \%, \mathrm{w} / \mathrm{v})]$ as growth factors. Growth was followed turbidometrically by measuring the increase in $\mathrm{OD}_{660}$.

In vivo absorption spectra were measured with a Spectronic Genesys 2 spectrophotometer in sucrose solution (Trüper \& Pfennig, 1981). For pigment analysis, $1 \mathrm{l}$ of $48 \mathrm{~h}$ grown culture was harvested by centrifugation (16000 r.p.m. for $10 \mathrm{~min}$ ). The supernatant was discarded and the pellet was washed twice with $0.9 \% \mathrm{NaCl}$ solution and lyophilized. Pigments were extracted from lyophilized cells with methanol/acetone $(2: 7, \mathrm{v} / \mathrm{v})$. Carotenoid composition was analysed by using HPLC [solvent system, acetonitrile/ methanol/ethyl acetate $(50: 40: 10)$; flow rate, $1 \mathrm{ml} \mathrm{min}^{-1}$; column, luna $5 \mu \mathrm{m}, \mathrm{C} 18,250 \times 4.6 \mathrm{~mm}$ phenomenex; photo diode array detector (400-800 nm); wavelengths monitored, 450, 500 and $550 \mathrm{~nm}$ ]. Cellular fatty acids were methylated, separated and identified according to the instructions for the Microbial Identification System (Microbial ID; MIDI 6.0 version) [Sasser (1990); revised, www.midi-inc.com] which was outsourced through the Royal Research Laboratories, Secunderabad, India. Cells of all strains of Rhodopseudomonas grown photoheterotrophically on pyruvate $(25 \mathrm{mM})$ and ammonium chloride ( $7 \mathrm{mM}$ ) broth at $37^{\circ} \mathrm{C}$ were harvested by centrifugation $\left(10000 \times g\right.$ for $15 \mathrm{~min}$ at $\left.4{ }^{\circ} \mathrm{C}\right)$ on reaching cell densities of $70 \%$ of the maximum OD and the lyophilized pellet was used for fatty acid analysis.

Polar lipids were extracted from $1 \mathrm{~g}$ freeze-dried cells with methanol/chloroform/saline $(2: 1: 0.8$, by vol.) as described by Kates (1986). Lipids were separated using silica gel TLC (Kieselgel $60 \mathrm{~F}_{254}$; Merck) by two-dimensional chromatography using chloroform/methanol/water $(75: 32: 4$, by vol.) in the first dimension and chloroform/methanol/ acetic acid/water $(86: 16: 15: 4$, by vol.) in the second dimension (modified after Tindall, 1990a, b; Oren et al., 1996). Total polar lipid profiles were detected by spraying with $5 \%$ ethanolic molybdophosphoric acid and further characterized by spraying with ninhydrin (specific for amino groups), molybdenum blue (specific for phosphates), Dragendorff reagent (quaternary nitrogen) or $\alpha$ naphthol (specific for sugars) (Kates, 1972; Oren et al., 1996). Hopanoids were visualized at $360 \mathrm{~nm}$ after spraying with $0.1 \%$ solution of barberine chlorohydrate in ethanol (Neunlist et al., 1985). Quinones were extracted with a chloroform/methanol $(2: 1, \mathrm{v} / \mathrm{v})$ mixture, purified by TLC and analysed by HPLC (Imhoff, 1984; Hiraishi \& Hoshino, 1984; Hiraishi et al., 1984).

Genomic DNA was extracted and purified according to the method of Marmur (1961) and the DNA G +C content was determined by HPLC (Mesbah et al., 1989). Cell material for $16 \mathrm{~S}$ rRNA gene sequencing was taken from a 
Table 1. Differential characteristics of strains $\mathrm{JA} 531^{\top}$ and $\mathrm{JA} 310^{\top}$ and other members of the genus Rhodopseudomonas

Taxa: 1, Rhodopseudomonas harwoodiae sp. nov. JA531 ${ }^{\mathrm{T}}$ (includes data for the additional strains JA447 and JA490; data that varies between strains is separated by a solidus); 2, Rhodopseudomonas parapalustris sp. nov. JA310 ${ }^{\mathrm{T}}$; 3 , Rhodopseudomonas pseudopalustris sp. nov. DSM $123^{\mathrm{T}}$; 4 , Rhodopseudomonas palustris ATCC $17001^{\mathrm{T}}$; 5, Rhodopseudomonas faecalis JCM $11668^{\mathrm{T}} ; 6$, Rhodopseudomonas rhenobacensis DSM $12706^{\mathrm{T}}$. Data are from this study. For all taxa, organic substrate utilization was tested during photoheterotrophic growth. Acetate, lactate and pyruvate are utilized by all strains. None of the strains could utilize citrate, fructose, mannitol, methanol or aspartate. Intracellular photosynthetic membranes are of the lamellae type for all strains. All strains have $\mathrm{Bchl} a$, are tryptophanase-negative, have no salt requirement, assimilate sulfate, do not ferment glucose/ fructose and have Q-10 as major quinone. +, Substrate utilized/present; -, substrate not utilized/absent; (+), weak growth; NA, not available.

\begin{tabular}{|c|c|c|c|c|c|c|}
\hline Characteristic & 1 & 2 & 3 & 4 & 5 & 6 \\
\hline Isolation source & $\begin{array}{l}\text { Saltpan/pond } \\
\text { sediment }\end{array}$ & Soil & Soil/pond water & $\begin{array}{c}\text { Soil/sludge/pond } \\
\text { water }\end{array}$ & Chicken faeces & Eutrophic pond \\
\hline \multicolumn{7}{|l|}{ Cell size $(\mu \mathrm{m})$} \\
\hline Width & $0.8-1.0$ & $0.8-1.2$ & $0.5-1.0$ & $0.4-1.0$ & $0.6-0.8$ & $0.4-0.6$ \\
\hline Type of budding & Tube & Sessile & Sessile & Tube & Sessile & Sessile \\
\hline Colour of cultures ${ }^{\star}$ & $\mathrm{R}$ & $\mathrm{RB}$ & $\mathrm{RB}$ & $\mathrm{RB}$ & $\mathrm{R}$ & $\mathrm{R}$ \\
\hline \multicolumn{7}{|l|}{ Growth pH } \\
\hline Optimum & $6.0-7.5$ & $6.5-7.0$ & $6.0-8.0$ & $6.5-8.5$ & 7.0 & 5.5 \\
\hline Range & $5.0-9.0$ & $6.0-9.0$ & 7.0 & $6.0-9.0$ & $6.5-7.0$ & $5.0-7.0$ \\
\hline \multicolumn{7}{|l|}{ Growth temperature $\left({ }^{\circ} \mathrm{C}\right)$} \\
\hline $\begin{array}{l}\text { Photoautotrophic } \\
\text { growth }\end{array}$ & - & - & - & $\begin{array}{l}\text { With } \mathrm{H}_{2} \text {, thiosulfate, } \\
\text { sulfide }\end{array}$ & $\begin{array}{l}\text { With } \mathrm{H}_{2} \text {, sodium } \\
\text { bicarbonate }\end{array}$ & - \\
\hline Growth factors & PABA & Thiamine, PABA & PABA & $\mathrm{PABA} \dagger$ & Thiamine & PABA \\
\hline Major polar lipids $\ddagger$ & $\begin{array}{l}\text { DPG, PG, PE, PC, } \\
\text { AL1-2, AL6, AL8, } \\
\text { PL1, AH, L2-4, L6 }\end{array}$ & $\begin{array}{l}\text { DPG, PG, PE, } \\
\text { PC, AL1, AL3, } \\
\text { PL1, AH, L2-4 }\end{array}$ & $\begin{array}{l}\text { DPG, PG, PE, } \\
\text { PC, AL1, AL3, } \\
\text { PL1, AH, L1-5 }\end{array}$ & $\begin{array}{l}\text { DPG, PG, PE, } \\
\text { PC, AL1-4, PL1, } \\
\text { AH, L1-4 }\end{array}$ & $\begin{array}{l}\text { DPG, PG, PE, } \\
\text { PC, AL1-7, PL1, } \\
\text { AH, L1-5 }\end{array}$ & $\begin{array}{l}\text { DPG, PG, PE, } \\
\text { PC, AL1, AL4, } \\
\text { PL1, AH, L1-4 }\end{array}$ \\
\hline \multicolumn{7}{|l|}{$\begin{array}{l}\text { Fatty acid composition } \\
(\%)\end{array}$} \\
\hline $\mathrm{C}_{12: 0}$ & - & 1.1 & 2.4 & 1.6 & 1.7 & 0.2 \\
\hline $\mathrm{C}_{14: 0}$ & - & - & - & 1.8 & - & - \\
\hline $\mathrm{C}_{14: 0} 2-\mathrm{OH}$ & - & - & 1.0 & - & - & 0.1 \\
\hline $\mathrm{C}_{18: 1} \omega 7 c$ & 74.2 & 53.2 & 56.5 & 51 & 63 & 69.6 \\
\hline 11-Methyl $\mathrm{C}_{18: 1} \omega 7 c$ & 3.2 & 7.5 & 4.0 & 4.3 & 5.8 & 1.8 \\
\hline iso- $\mathrm{C}_{19: 0}$ & - & - & 4.2 & 0.3 & - & 0.2 \\
\hline $\mathrm{C}_{20: 0}$ & - & 1.3 & 2.4 & 0.1 & - & 0.1 \\
\hline $\mathrm{C}_{20: 1} \omega 7 c$ & - & 1.2 & - & 0.2 & - & 0.2 \\
\hline \multicolumn{7}{|l|}{$\begin{array}{l}\text { Organic substrates } \\
\text { supporting growth }\end{array}$} \\
\hline Benzoatell & + & - & + & + & - & - \\
\hline Butyrate & + & - & + & + & + & + \\
\hline Caproate & + & - & + & $(+)$ & $(+)$ & - \\
\hline Caprylate & - & - & + & - & - & - \\
\hline Ethanol & - & - & + & + & - & + \\
\hline Formate & - & - & + & - & - & + \\
\hline
\end{tabular}


Table 1. cont.

\begin{tabular}{|c|c|c|c|c|c|c|}
\hline Characteristic & 1 & 2 & 3 & 4 & 5 & 6 \\
\hline Fumarate & $(+)$ & + & + & + & $(+)$ & + \\
\hline D-Glucose & - & $(+)$ & + & + & + & - \\
\hline Glycerol & $(+) /-$ & + & + & + & - & $(+)$ \\
\hline Glycolate & - & - & + & $\mathrm{NA}$ & - & - \\
\hline Malate & - & + & + & + & + & + \\
\hline Propanol & - & - & + & NA & - & - \\
\hline Propionate & $(+)$ & - & + & + & $(+)$ & - \\
\hline Sorbitol & - & + & + & NA & - & - \\
\hline Succinate & $(+)$ & + & + & + & + & + \\
\hline Tartrate & - & - & - & - & - & + \\
\hline Valerate & + & - & + & NA & - & - \\
\hline 3 & $45 \pm 9.2$ & $48 \pm 4.2$ & 100 & & & \\
\hline 4 & $47.5 \pm 4.4$ & $45.3 \pm 2.8$ & $32.8 \pm 3.8(25)$ & 100 & & \\
\hline 5 & $28.4 \pm 2.9$ & $32.1 \pm 2.2$ & $41 \pm 8.3(25)$ & $40.7 \pm 2(18)$ & 100 & \\
\hline 6 & $27 \pm 4.6$ & $24.1 \pm 3.8$ & $32.5 \pm 14.5(20)$ & $38.6 \pm 4.4(29)$ & $43.5 \pm 4.2(25)$ & 100 \\
\hline $\begin{array}{l}\text { DNA G + C content } \\
(\mathrm{mol} \% \text {; HPLC })\end{array}$ & 62.4 & 63.8 & 65.8 & 64.9 & 64.0 & 65.4 \\
\hline
\end{tabular}

${ }^{*} \mathrm{R}$, Red; RB, red-brown.

$\dagger$ A few strains require biotin.

¥AH, Aminohopanoid; AL1-8, unknown aminolipids; DPG, diphosphatidylglycerol; L1-6, unknown lipids; PC, phosphatidylcholine; PE, phosphatidylethanolamine; PG, phosphatidylglycerol; and PL, unknown phospholipid. Numbering of polar lipids is according to the convention adopted by Kämpfer et al. (2006).

$\$$ Alcohol (not a fatty acid).

IITested at 0.5 and $1.0 \mathrm{mM}$.

SData given are the mean and standard deviation values of three independent experiments performed in triplicate for each sample (control: reversal of strains was used for binding and labelling). Values given in parentheses are from Okamura et al. (2009).

colony. DNA was extracted and purified by using a Qiagen genomic DNA extraction kit. Recombinant Taq polymerase (Genei) was used for PCR. The complete length of the $16 \mathrm{~S}$ rRNA gene sequence was obtained by sequencing with four primers, $\mathrm{F}^{\prime}-27$ (5'-GTTTGATCCTGGCTCAG$\left.3^{\prime}\right), \quad \mathrm{F}^{\prime}-372 \quad\left(5^{\prime}\right.$-TACGGGAGGCAGCAG-3'), $\mathrm{F}^{\prime}-790$ (5'-GGTTACCTTGTTACGACT-3') and R'-1489 (5'-TACCTTGTTACGACTTCA-3') [positions 11-27 and 14891506 for $\mathrm{F}^{\prime}-27$ and $\mathrm{R}^{\prime}-1489$, respectively, according to the Escherichia coli 16S rRNA numbering system of the International Union of Biochemistry (Brosius et al., 1978; Lane et al., 1985)]. PCR amplification was done as described previously (Imhoff \& Pfennig, 2001; Imhoff et al., 1998) and 16S rRNA gene sequences were obtained (without gene cloning) by cycle sequencing with a SequiTherm sequencing kit (Biozym) and chain termination reaction (Sanger et al., 1977) using an automated laser fluorescence sequencer (Pharmacia). The identification of phylogenetic neighbours and calculation of pairwise $16 \mathrm{~S}$ rRNA gene sequence similarities were achieved using an
NCBI BLAST search (Altschul et al., 1990) and the EzTaxon server (Chun et al., 2007). The CLUSTAL $\mathrm{w}$ algorithm of MEGA4 was used for sequence alignments and MEGA4 (Tamura et al., 2007) software was used for phylogenetic analysis of the individual sequences. Distances were calculated by using the Kimura two-parameter model (Kimura, 1980). Neighbour-joining and minimum evolution methods in the MEGA4 software (http://www.mega software.net/mega4/mega4.pdf) were used to reconstruct phylogenetic trees. Support values (\%) were obtained using a bootstrap procedure. The taxonomic relationship between strains of the genus Rhodopseudomonas was examined using genome DNA-DNA hybridization. Genomic relatedness was determined by a membrane filter technique (Seldin \& Dubnau, 1985; Tourova \& Antonov, 1988) using a DIG High Prime DNA labelling and detection starter kit II (Roche). Hybridization was performed with three replications for each sample (control: reversal of strains used for binding and labelling) and the mean values are quoted as DNA-DNA relatedness values. 
Four strains (JA310 ${ }^{\mathrm{T}}, \mathrm{JA} 531^{\mathrm{T}}$, JA447 and JA490) belonging to the genus Rhodopseudomonas were isolated from different geographical regions of India. Cells of all strains were rod-shaped, $0.8-1.2 \mu \mathrm{m}$ wide and $2.0-3.0 \mu \mathrm{m}$ long, and they multiplied by budding. Rosette formation was observed in old cultures of all strains. Cells of all strains were motile by means of polar flagella. Transmission electron micrographs of ultrathin sections of cells of the four strains revealed a lamellar type of internal membrane structure parallel to the cytoplasmic membrane. All strains were able to grow photo-organoheterotrophically [anaerobically in the light $(2400 \mathrm{~lx})$ with sodium pyruvate $(0.3 \%$ $\mathrm{w} / \mathrm{v}$ ) as carbon source] and chemo-organoheterotrophically [aerobically in the dark with sodium pyruvate $(0.3 \% \mathrm{w} / \mathrm{v})$ as carbon source]. Photolithoautotrophic [anaerobically in the light $(2400 \mathrm{~lx})$ ] and chemolithoautotrophic [aerobically in the dark] growth with $\mathrm{Na}_{2} \mathrm{~S}_{2} \mathrm{O}_{3} \cdot 5 \mathrm{H}_{2} \mathrm{O}(0.5 \mathrm{mM})$ as electron donor and $\mathrm{NaHCO}_{3}(0.1 \% \mathrm{w} / \mathrm{v})$ as carbon source could not be demonstrated in any of the isolates. Fermentative growth [anaerobic, dark with glucose/fructose/ pyruvate $(0.3 \% \mathrm{w} / \mathrm{v})$ ] could not be demonstrated in any of the strains. Organic substrates utilized/not utilized for growth by all four strains are given in Table 1. Benzoate $(0.5$ and $1.0 \mathrm{mM})$ could not support growth of strain $\mathrm{JA} 310^{\mathrm{T}}$, although it supported growth of strains $\mathrm{JA} 531^{\mathrm{T}}$, JA447 and JA490. Ammonium chloride, nitrate and asparagine supported growth of $J A 310^{\mathrm{T}}$, but urea, glutamate, glutamine and nitrite could not. Strains JA531 ${ }^{\mathrm{T}}$, JA447 and JA490 grew with ammonium chloride, glutamine and urea as nitrogen sources, but nitrite, nitrate and glutamate could not support growth. Strains JA531 ${ }^{\mathrm{T}}$, JA447 and JA490 exhibited diazotrophic growth, which was not observed in strain $\mathrm{JA} 310^{\mathrm{T}}$.

Both thiamine and PABA were required by strain $\mathrm{JA} 310^{\mathrm{T}}$, whereas strains JA531 ${ }^{\mathrm{T}}$, JA447 and JA490 had a requirement for PABA alone. Sulfate, $\mathrm{MgSO}_{4} \cdot 7 \mathrm{H}_{2} \mathrm{O}, \mathrm{Na}_{2} \mathrm{~S} .9 \mathrm{H}_{2} \mathrm{O}$, $\mathrm{Na}_{2} \mathrm{~S}_{2} \mathrm{O}_{3}$, thioglycolate and cysteine were used as sulfur sources, but sulfite did not support phototrophic growth of any of the four strains. $\mathrm{NaCl}$ was not obligatory for growth of the strains; strain JA531 ${ }^{\mathrm{T}}$ could tolerate up to $4 \% \mathrm{NaCl}$, whereas the other three strains tolerated up to $0.5 \% \mathrm{NaCl}$. The $\mathrm{pH}$ range for growth of strain $\mathrm{JA} 310^{\mathrm{T}}$ was $6.0-9.0$ (optimum pH 6.5-7.0), whereas strains JA531 ${ }^{\mathrm{T}}$, JA447 and JA490 grew at $\mathrm{pH}$ 5.0-9.0 (optimum $\mathrm{pH}$ 6.0-7.5). All four strains were mesophilic, with optimal growth at $30{ }^{\circ} \mathrm{C}$.

The colour of phototrophically-grown cell suspensions of strain JA310 ${ }^{\mathrm{T}}$ was reddish brown, whereas those of strains JA531 ${ }^{\mathrm{T}}$, JA447 and JA490 were red. Whole cell absorption spectra of all four strains showed absorption maxima at 524-528, 590-593, 806 and 863-869 nm (Fig. S1, available in IJSEM Online) confirming the presence of bacteriochlorophyll (Bchl) $a$ and carotenoids. Acetone extracts of all strains had absorption maxima at 445, 475 and $502 \mathrm{~nm}$, indicating the presence of carotenoids of the spirilloxanthin series (Britton et al., 2004). Carotenoid composition of strains $\mathrm{JA} 310^{\mathrm{T}}$, JA531 ${ }^{\mathrm{T}}$, JA447 and JA490 as detected by HPLC analysis was: rhodopin (21-25\%), 3,4-dihydrorhodopin (36-44\%), anhydrorhodovibrin (13-16\%), lycopene (3-4\%), rhodovibrin (5-7\%) and spirilloxanthin (5-6\%). Whole-cell fatty acid analysis revealed that $\mathrm{C}_{18: 1} \omega 7 c(51-74 \%)$ was the major fatty acid for all the strains tested and differences in the fatty acid composition among members of the genus Rhodopseudomonas are shown in Table 1. All strains contained ubiquinone-10 (Q-10) as the primary quinone component.

The polar lipid profile common to all Rhodopseudomonas strains tested consisted of diphosphatidylglycerol (DPG), phosphatidylglycerol (PG), phosphatidylethanolamine (PE) and phosphatidylcholine (PC) as major components, with moderate amounts of an unidentified phospholipid (PL), unidentified lipids (L2-4), an aminohopanoid (AH) and an unidentified aminolipid (AL1) (Table 1; Fig. S2). The major polar lipid composition observed in this study is in agreement with those of previous reports for members of the genera Rhodopseudomonas/Bradyrhizobium/Nitrobacter/ Afipia (Hougardy et al., 2000; Imhoff et al., 1982). The presence of $\mathrm{AH}$ is also in agreement with members of the genus Rhodopseudomonas (Neunlist et al., 1985; Hougardy et al., 2000). The absence of a few unidentified ALs (AL5-8) and other lipids (L5, 6) differentiated $R$. palustris ATCC $17001^{\mathrm{T}}$ from other type strains in the genus Rhodopseudomonas. Unidentified ALs (AL2, 4-8) and other lipids (L1, 5, 6) were absent in strain JA310 ${ }^{\mathrm{T}}$. The presence of AL8 and L6 was unique to strain JA531 ${ }^{\mathrm{T}}$. R. rhenobacensis DSM $12706^{\mathrm{T}}$ could be differentiated from other members by the absence of unidentified AL2-8 and other lipids (L5, 6). R. faecalis JCM $11668^{\mathrm{T}}$ possessed unidentified AL5 and AL7, which were not observed in other members of the genus. An unidentified lipid (L5) was present in strain DSM $123^{\mathrm{T}}$ alone, whereas unidentified AL2, AL4-8 and L6 were absent in this strain. A few unidentified polar lipids (PL, L1-4) were not previously reported in $R$. rhenobacensis DSM $12706^{\mathrm{T}}$ (Hougardy et al., 2000).

The genomic DNA G $+\mathrm{C}$ content of strain $J A 310^{\mathrm{T}}$ was $63.8 \mathrm{~mol} \%$ and those of strains JA531 ${ }^{\mathrm{T}}$, JA447, JA490 were 62.4-63.3 mol\% (by HPLC). The phylogenetic relationship (Fig. 1) between strains JA310 ${ }^{\mathrm{T}}$, JA531 ${ }^{\mathrm{T}}$, JA447 and JA490 and other closely related bacteria was examined using $16 \mathrm{~S}$ rRNA gene sequence analysis. The data obtained revealed that the novel isolates clustered with the type strains of species of the genus Rhodopseudomonas, but were distinct from phototrophic and chemotrophic members of other genera. The neighbour-joining tree (Fig. 1; tree topology was similar in minimum evolution, unweighted pair group method with arithmetic averages and maximum-likelihood trees and a multiple sequence alignment file is available in IJSEM Online) revealed three distinct subclades within the genus Rhodopseudomonas. Strains JA531 ${ }^{\mathrm{T}}$, JA447 and JA490 formed a distinct microclade. $R$. palustris ATCC $17001^{\mathrm{T}}$ and $R$. faecalis JCM $11668^{\mathrm{T}}$ clustered together, but strain $\mathrm{JA} 310^{\mathrm{T}}$, along with strain DSM $123^{\mathrm{T}}$ and $R$. rhenobacensis DSM $12706^{\mathrm{T}}$ were separate from the rest of the members of the genus. Strains JA3 $310^{\mathrm{T}}$ and JA531 


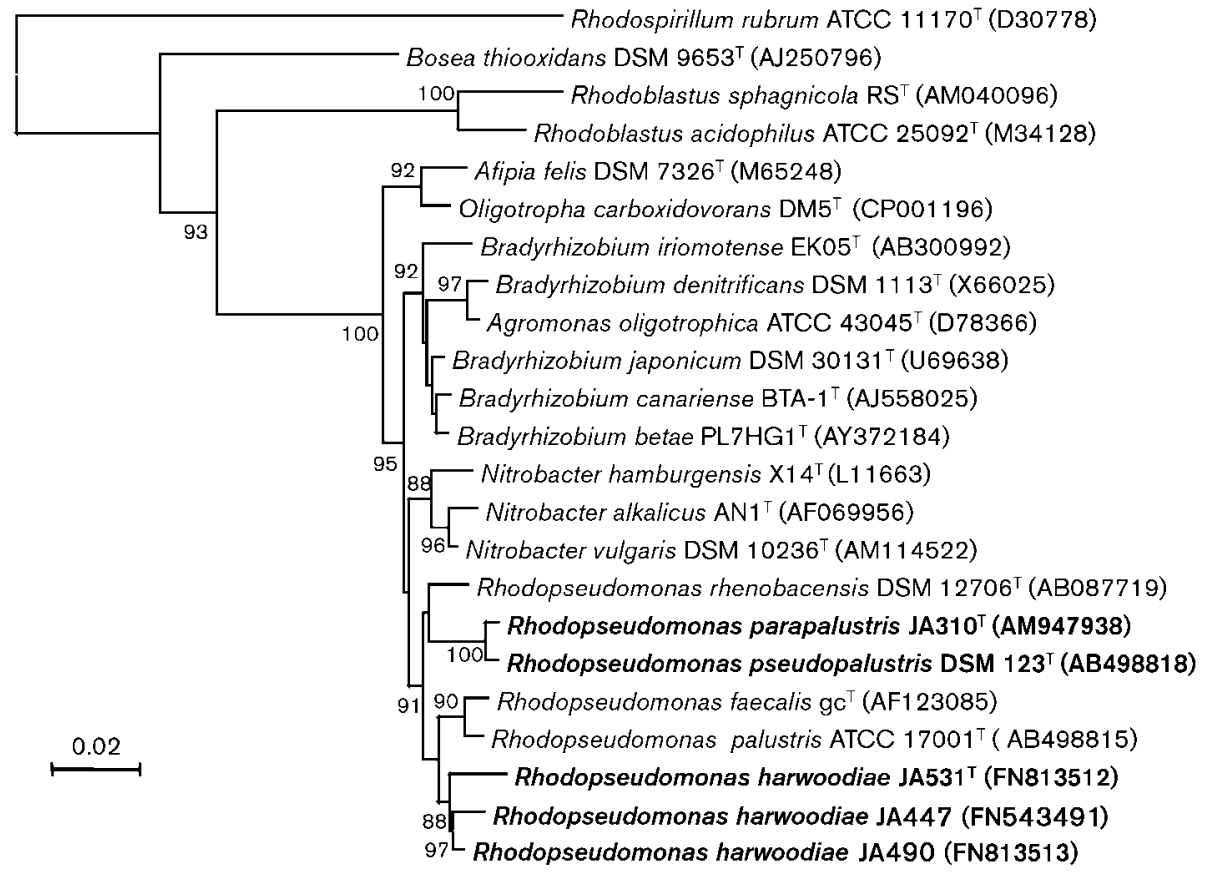

Fig. 1. Dendrogram based on $16 \mathrm{~S}$ rRNA gene sequences depicting the phylogenetic relationships of strains $J A 310^{\top}, J A 531^{\top}$, JA447, JA490 and DSM $123^{\top}$ with members of the genus Rhodopseudomonas and other chemotrophic genera. The tree was reconstructed (1350 gap-free sites were compared) by the neighbour-joining method using the MEGA4 software. Bootstrap values (percentages from 500 replicates) are shown next to the corresponding branch. Bar, 2 nucleotide substitutions per $100 \mathrm{nt}$.

showed the highest gene sequence similarities to $R$. palustris ATCC $17001^{\mathrm{T}}$ (96.3 and $97.5 \%$, respectively), R. faecalis JCM $11668^{\mathrm{T}}$ (96.7 and $97.3 \%$ ) and $R$. rhenobacensis DSM $12706^{\mathrm{T}}$ (97.4 and $\left.97.1 \%\right)$. Strains JA $310^{\mathrm{T}}$ and JA531 ${ }^{\mathrm{T}}$ had about $96.3 \% 16 \mathrm{~S}$ rRNA gene sequence similarity.

DNA-DNA hybridization of strains JA $310^{\mathrm{T}}$ and $\mathrm{JA} 531^{\mathrm{T}}$ (JA447 and JA490) with the most closely related type strains of members of the genus Rhodopseudomonas revealed relatedness values of $24-48 \%$, whereas strains $\mathrm{JA} 310^{\mathrm{T}}$ and $\mathrm{JA} 531^{\mathrm{T}}$ were about $33.0 \%$ related (Table 1). Furthermore, strains JA447 and JA490 showed 79-89\% DNA relatedness to strain JA531 ${ }^{\mathrm{T}}$ and phenotypic traits were very similar to those of strain JA531 ${ }^{\mathrm{T}}$; thus, we propose that strains JA447 and JA490 are additional strains of a novel species represented by JA531 ${ }^{\mathrm{T}}$. Relatedness levels among other members of the genus Rhodopseudomonas were also determined; as suggested by Okamura et al. (2009), data confirmed that strains DSM $123^{\mathrm{T}}$ and ATCC $17001^{\mathrm{T}}$ are not members of the same species. DNA-DNA hybridization data were supported by differences in whole-cell fatty acid profile, polar lipid composition, vitamin requirements, $\mathrm{pH}$ optima and range, temperature range, organic substrate and electron donor utilization (Table 1; particularly benzoate utilization), nitrogen, sulfur source utilization and cell size (strain DSM $123^{\mathrm{T}}$ has long cells). Our data justify the description of strains JA $310^{\mathrm{T}}, \mathrm{JA} 531^{\mathrm{T}}$ and DSM $123^{\mathrm{T}}$ as representatives of three novel species, for which the names Rhodopseudomonas parapalustris sp. nov., Rhodopseudomonas harwoodiae sp. nov. and Rhodopseudomonas pseudopalustris sp. nov. are proposed, respectively.

\section{Description of Rhodopseudomonas parapalustris sp. nov.}

Rhodopseudomonas parapalustris (pa.ra.pa.lus'tris. Gr. prep. para alongside of, resembling; L. fem. adj. palustris marshy, and also a bacterial epithet; N.L. fem. adj. parapalustris resembling Rhodopseudomonas palustris).

Cells are rod-shaped, $0.8-1.2 \mu \mathrm{m}$ wide and $2.0-4.0 \mu \mathrm{m}$ long. Cells are motile by means of polar flagella and multiply by budding. Cells of old cultures form rosettes. Internal photosynthetic membranes are present as lamellar stacks parallel to the cytoplasmic membrane. Phototrophically grown cultures are reddish brown. The in vivo absorption spectrum of intact cells in sucrose exhibits maxima at 497, 590, 800 and $863 \mathrm{~nm}$. Bchl $a$ and carotenoids of the spirilloxanthin series are present. The type strain is mesophilic (range $15-35{ }^{\circ} \mathrm{C}$ ). $\mathrm{No} \mathrm{NaCl}$ is required for growth (tolerates up to $0.5 \%, \mathrm{w} / \mathrm{v}$ ) and growth $\mathrm{pH}$

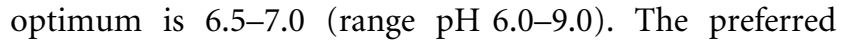
mode of growth is photo-organoheterotrophy with a few organic compounds. Good growth is observed with malate, succinate, pyruvate, glycerol, fumarate and sorbitol as carbon sources. Phototrophic growth also occurs on 
D-glucose. Benzoate, butyrate, caproate, caprylate, ethanol, formate, glutamate, glycolate, malonate, propanol, propionate, tartrate and valerate are not utilized as carbon sources. Photoautotrophic and chemoautotrophic growth with thiosulfate $/ \mathrm{H}_{2} /$ sulfide/sulfur/sulfite/thioglycolate as electron donor and $\mathrm{NaHCO}_{3}$ as carbon source is not observed. Fermentative growth does not occur in the presence of glucose, fructose or pyruvate. Nitrate and aspartate are used as nitrogen sources. Diazotrophy is absent. Sulfate, thiosulfate, thioglycolate and cysteine are used as sulfur sources. Thiamine and PABA are required as growth factors. $\mathrm{C}_{18: 1} \omega 7 c$ is the major fatty acid, with moderate amounts of $\mathrm{C}_{12: 0}, \mathrm{C}_{16: 0}, 11$-methyl $\mathrm{C}_{18: 1} \omega 7 c, \mathrm{C}_{18: 0}$ and $\mathrm{C}_{16: 1} \omega 7 c / \omega 6 c$. Ubiquinone-10 is the major quinone. DPG, PG, PE, PC and AL1 are the major polar lipids. Moderate amounts of AL3, PL and other lipids (L2-4) are also present. $\mathrm{AH}$ is present.

The type strain is JA310 ${ }^{\mathrm{T}}\left(=\mathrm{NBRC} 106083^{\mathrm{T}}=\mathrm{KCTC} 5839^{\mathrm{T}}\right)$, isolated from a sediment soil sample taken near Pangong Lake at Leh, Jammu and Kashmir, India. The genomic DNA $\mathrm{G}+\mathrm{C}$ of the type strain is $63.8 \mathrm{~mol} \%$ (by HPLC). Natural habitats are surface soils near lakes at high altitudes.

\section{Description of Rhodopseudomonas harwoodiae sp. nov.}

Rhodopseudomonas harwoodiae [har.wo.o.di'a.e. N.L. fem. gen. n. harwoodiae of Harwood, named after Professor Dr C. S. Harwood, a microbiologist who has significantly contributed to the knowledge of aromatic hydrocarbon metabolism of Rhodopseudomonas palustris strain CGA009, the genome sequence of which is available from GenBank/ EMBL/DDBJ under accession numbers BX571963 (chromosome) and BX571964 (plasmid) (Larimer et al., 2004)].

Cells are rod-shaped, 0.8-1.0 $\mu \mathrm{m}$ wide and 2.0-3.5 $\mu \mathrm{m}$ long, and motile; division is by budding and cells have lamellar internal cytoplasmic membrane structures. Phototrophic cultures are red. In vivo absorption spectra of intact cells exhibit maxima at 497, 590, 605 and $863 \mathrm{~nm}$. Bchl $a$ and carotenoids of the spirilloxanthin series are present. No $\mathrm{NaCl}$ is required for growth; the type strain tolerates up to $4 \% \mathrm{NaCl}$, whereas other strains tolerate up to $0.5 \%(\mathrm{w} / \mathrm{v})$. Mesophilic (range $25-40{ }^{\circ} \mathrm{C}$ ) with optimum growth at pH 6.0-7.5 (range pH 5.0-9.0). The preferred mode of growth is photo-organoheterotrophy with a few organic compounds. Good growth occurs on benzoate, butyrate, caproate and valerate. Feeble growth occurs with fumarate, glycerol, malonate, propionate and succinate as carbon sources. Caprylate, ethanol, formate, D-glucose, glutamate, glycolate, malate, propanol, sorbitol and tartrate do not support growth. Photoautotrophic and fermentative growth is absent. PABA is required as growth factor. Diazotrophy is present. $\mathrm{C}_{18: 1} \omega 7 c$ is the major fatty acid, with moderate amounts of $\mathrm{C}_{16: 0}, \mathrm{C}_{18: 0}, 11$-methyl $\mathrm{C}_{18: 1} \omega 7 c$ and $\mathrm{C}_{16: 1} \omega 7 \mathrm{cl}$ $\omega 6 c$. Ubiquinone-10 is the major quinone. DPG, PG, PE, $\mathrm{AL} 1$ and $\mathrm{PC}$ are the major polar lipids. Moderate amounts of unidentified ALs (AL2, 6, 8), PL and other lipids (L2-4, 6) are also present. $\mathrm{AH}$ is present.

The type strain is $\mathrm{JA} 531^{\mathrm{T}}\left(=\mathrm{NBRC} 107575^{\mathrm{T}}=\mathrm{KCTC} 5841^{\mathrm{T}}\right)$, isolated from sediment of a saltpan at Kalambakam, Tamil Nadu, India. The DNA G $+C$ content of the type strain is $62.4 \mathrm{~mol} \%$ (by HPLC). Additional strains JA447 and JA490, which were isolated from freshwater sediments from different geographical regions of India, have properties similar to the type strain JA531 ${ }^{\mathrm{T}}$. Natural habitats are salterns of coastal ecosystems and freshwater sediments.

\section{Description of Rhodopseudomonas pseudopalustris sp. nov.}

Rhodopseudomonas pseudopalustris (pseu.do.pa'lus.tris. Gr. adj. pseudês false; L. fem. adj. palustris marshy, and also a bacterial epithet; N.L. fem. adj. pseudopalustris the false [Rhodopseudomonas] palustris).

Cells are rod-shaped, $0.8-1.0 \mu \mathrm{m}$ wide and $2.0-6.0 \mu \mathrm{m}$ long, and motile; division is by budding and cells have lamellar internal cytoplasmic membrane structures. Phototrophic cultures are reddish brown. In vivo absorption spectra of intact cells exhibit maxima at 497, 590, 605 and $865 \mathrm{~nm}$. Bchl $a$ and carotenoids of the spirilloxanthin series are present. No $\mathrm{NaCl}$ is required for growth (tolerates up to $0.5 \%, \mathrm{w} / \mathrm{v}$ ). Mesophilic (range $20-35{ }^{\circ} \mathrm{C}$ ) with optimum growth at $\mathrm{pH} 7.0$ (range $\mathrm{pH}$ 6.0-8.0). The preferred mode of growth is photo-organoheterotrophy with a few organic compounds. Good growth occurs on benzoate, formate, butyrate, caproate, caprylate, fumarate, glutamate, glycerol, glycolate, malate, malonate, propanol, propionate, sorbitol, succinate and valerate. Feeble growth occurs with ethanol and D-glucose. Tartrate does not support growth. Photoautotrophic and fermentative growth is absent. PABA is required as a growth factor. $\mathrm{C}_{18: 1} \omega 7 c$ is the major fatty acid with moderate amounts of $\mathrm{C}_{12: 0}, \mathrm{C}_{16: 0}$, $\mathrm{C}_{18: 0}, 11$-methyl $\mathrm{C}_{18: 1} \omega 7 c, \mathrm{C}_{16: 1} \omega 7 c / \omega 6 c$, iso- $\mathrm{C}_{19: 0}$ and $\mathrm{C}_{20: 0}$. Ubiquinone-10 is the major quinone. DPG, PG, PE, AL1 and PC are the major polar lipids. Moderate amounts of AL3, PL and other lipids (L1-5) are also present. AH is present.

The type strain is DSM $123^{\mathrm{T}}$ (=NBRC $100419^{\mathrm{T}}$; confirmed by Okamura et al., 2009), which was isolated by van Niel (1944). The DNA G+C content of the type strain is $65.8 \mathrm{~mol} \%$ (by HPLC).

\section{Emended description of Rhodopseudomonas palustris}

The description of the species is as given previously (Imhoff, 2005). DPG, PG, PE, AL1 and PC are the major polar lipids. Moderate amounts of AL2-4, PL1 and other lipids (L1-4) are also present. AH is present.

The type strain is ATH2.1.6 $6^{\mathrm{T}}$ (=ATCC $17001^{\mathrm{T}}$ ). The DNA $\mathrm{G}+\mathrm{C}$ content of the type strain is $64.9 \mathrm{~mol} \%$ (by HPLC). 


\section{Acknowledgements}

Financial assistance received from Department of Biotechnology, Government of India, is greatly acknowledged. We thank Professor J. Euzéby for his expert suggestion for the correct species epithet and Latin etymology. V.V.R., S. K.C. and E.V.V.R. acknowledge the CSIR, Government of India, for the award of an SR fellowship. P. S. R. and B.V.K. acknowledge JNTU Hyderabad for a research fellowship award.

\section{References}

Altschul, S. F., Gish, W., Miller, W., Myers, E. W. \& Lipman, D. J. (1990). Basic local alignment search tool. J Mol Biol 215, 403-410.

Britton, G., Liaaen-Jensen, S. \& Pfander, H. (2004). Carotenoids with a $\mathrm{C}_{40}$ skeleton (b) hydroxycarotenoids. In Carotenoids Handbook, Main List, pp. 51-212. Edited by G. Britton, S. Liaaen-Jensen \& H. Pfander. Basel, Boston \& Berlin: Birkhauser Verlag.

Brosius, J., Palmer, M. L., Kennedy, P. J. \& Noller, H. F. (1978). Complete nucleotide sequence of a $16 \mathrm{~S}$ ribosomal RNA gene from Escherichia coli. Proc Natl Acad Sci U S A 75, 4801-4805.

Chun, J., Lee, J.-H., Jung, Y., Kim, M., Kim, S., Kim, B. K. \& Lim, Y. W. (2007). EzTaxon: a web-based tool for the identification of prokaryotes based on $16 \mathrm{~S}$ ribosomal RNA gene sequences. Int J Syst Evol Microbiol 57, 2259-2261.

Czurda, V. \& Maresch, E. (1937). Beitrag zur Kenntnis der Athiorhodobakterien-Gesellschaften. Arch Mikrobiol 8, 99-124 (in German).

Hiraishi, A. (1997). Transfer of the bacteriochlorophyll $b$-containing phototrophic bacteria Rhodopseudomonas viridis and Rhodopseudomonas sulfoviridis to the genus Blastochloris gen. nov. Int J Syst Bacteriol 47, 217-219.

Hiraishi, A. \& Hoshino, Y. (1984). Distribution of rhodoquinone in Rhodospirillaceae and its taxonomic implications. J Gen Appl Microbiol 30, 435-448.

Hiraishi, A. \& Ueda, Y. (1994). Rhodoplanes gen. nov., a new genus of phototrophic bacteria including Rhodopseudomonas rosea as Rhodoplanes roseus comb. nov. and Rhodoplanes elegans sp. nov. Int J Syst Bacteriol 44, 665-673.

Hiraishi, A., Hoshino, Y. \& Kitamura, H. (1984). Isoprenoid quinone composition in the classification of Rhodospirillaceae. J Gen Appl Microbiol 30, 197-210.

Hougardy, A., Tindall, B. J. \& Klemme, J. H. (2000). Rhodopseudomonas rhenobacensis sp. nov., a new nitrate-reducing purple non-sulfur bacterium. Int J Syst Evol Microbiol 50, 985-992.

Imhoff, J. F. (1984). Quinones of phototrophic purple bacteria. FEMS Microbiol Lett 25, 85-89.

Imhoff, J. F. (2005). Genus Rhodopseudomonas. In Bergey's Manual of Systematic Bacteriology, 2nd edn, vol. 2, pp. 473-476. Edited by D. J. Brenner, N. R. Krieg, J. T. Staley \& G. M. Garrity. New York: Springer.

Imhoff, J. F. \& Pfennig, N. (2001). Thioflavicoccus mobilis gen. nov., sp. nov., a novel purple sulfur bacterium with bacteriochlorophyll $b$. Int $J$ Syst Evol Microbiol 51, 105-110.

Imhoff, J. F., Kushner, D. J., Kushwaha, S. C. \& Kates, M. (1982). Polar lipids in phototrophic bacteria of the Rhodospirillaceae and Chromatiaceae families. J Bacteriol 150, 1192-1201.

Imhoff, J. F., Trüper, H. G. \& Pfennig, N. (1984). Rearrangement of the species and genera of the phototrophic "purple nonsulfur bacteria". Int J Syst Bacteriol 34, 340-343.

Imhoff, J. F., Süling, J. \& Petri, R. (1998). Phylogenetic relationships among the Chromatiaceae, their taxonomic reclassification and description of the new genera Allochromatium, Halochromatium, Isochromatium, Marichromatium, Thiococcus, Thiohalocapsa and Thermochromatium. Int J Syst Bacteriol 48, 1129-1143.

Kämpfer, P., Rosselló-Mora, R., Scholz, H. C., Welinder-Olsson, C., Falsen, E. \& Busse, H.-J. (2006). Description of Pseudochrobactrum gen. nov., with the two species Pseudochrobactrum asaccharolyticum sp. nov. and Pseudochrobactrum saccharolyticum sp. nov. Int J Syst Evol Microbiol 56, 1823-1829.

Kates, M. (1972). Techniques of Lipidology. New York: Elsevier.

Kates, M. (1986). Techniques of Lipidology: Isolation, Analysis, and Identification of Lipids. Amsterdam: Elsevier.

Kimura, M. (1980). A simple method for estimating evolutionary rates of base substitutions through comparative studies of nucleotide sequences. J Mol Evol 16, 111-120.

Lakshmi, K. V. N. S., Sasikala, Ch. \& Ramana, Ch. V. (2009). Rhodoplanes pokkaliisoli sp. nov., a phototrophic alphaproteobacterium isolated from a waterlogged brackish paddy soil. Int J Syst Evol Microbiol 59, 2153-2157.

Lane, D. J., Pace, B., Olsen, G. J., Stahl, D. A., Sogin, M. L. \& Pace, N. R. (1985). Rapid determination of $16 \mathrm{~S}$ ribosomal RNA sequences for phylogenetic analyses. Proc Natl Acad Sci U S A 82, 69556959.

Larimer, F. W., Chain, P., Hauser, L., Lamerdin, J., Malfatti, S., Do, L., Land, M. L., Pelletier, D. A., Beatty, J. T. \& other authors (2004). Complete genome sequence of the metabolically versatile photosynthetic bacterium Rhodopseudomonas palustris. Nat Biotechnol 22, 5561.

Marmur, J. (1961). A procedure for the isolation of deoxyribonucleic acid from micro-organisms. J Mol Biol 3, 208-218.

Mesbah, M., Premachandran, U. \& Whitman, W. B. (1989). Precise measurement of the $\mathrm{G}+\mathrm{C}$ content of deoxyribonucleic acid by highperformance liquid chromatography. Int J Syst Bacteriol 39, 159167.

Neunlist, S., Holst, O. \& Rohmer, M. (1985). Prokaryotic triterpenoids. The hopanoids of the purple non-sulphur bacterium Rhodomicrobium vannielii: an aminotriol and its aminoacyl derivatives, $\mathrm{N}$-tryptophanyl and $\mathrm{N}$-ornithinyl aminotriol. Eur J Biochem 147, 561-568.

Okamura, K., Takata, K. \& Hiraishi, A. (2009). Intrageneric relationships of members of the genus Rhodopseudomonas. J Gen Appl Microbiol 55, 469-478.

Oren, A., Duker, S. \& Ritter, S. (1996). The polar lipid composition of Walsby's square bacterium. FEMS Microbiol Lett 138, 135-140.

Sanger, F., Nicklen, S. \& Coulson, A. R. (1977). DNA sequencing with chain-terminating inhibitors. Proc Natl Acad Sci U S A 74, 54635467.

Sasser, M. (1990). Identification of bacteria by gas chromatography of cellular fatty acids, MIDI Technical Note 101. Newark, DE: MIDI Inc.

Seldin, L. \& Dubnau, D. (1985). Deoxyribonucleic acid homology among Bacillus polymyxa, Bacillus macerans, Bacillus azotofixans, and other nitrogen-fixing Bacillus strains. Int J Syst Bacteriol 35, 151154.

Srinivas, T. N. R., Kumar, P. A., Sasikala, Ch. \& Ramana, Ch. V. (2007). Rhodovulum imhoffii sp. nov. Int J Syst Evol Microbiol 57, 228232.

Tamura, K., Dudley, J., Nei, M. \& Kumar, S. (2007). MEGA4: molecular evolutionary genetics analysis (MEGA) software version 4.0. Mol Biol Evol 24, 1596-1599.

Tindall, B. J. (1990a). Lipid composition of Halobacterium lacusprofundi. FEMS Microbiol Lett 66, 199-202. 
Tindall, B. J. (1990b). A comparative study of the lipid composition of Halobacterium saccharovorum from various sources. Syst Appl Microbiol 13, 128-130.

Tindall, B. J., Rosselló-Móra, R., Busse, H.-J., Ludwig, W. \& Kämpfer, P. (2010). Notes on the characterization of prokaryote strains for taxonomic purposes. Int J Syst Evol Microbiol 60, 249-266.

Tourova, T. P. \& Antonov, A. S. (1988). Identification of microorganisms by rapid DNA-DNA hybridization. Methods Microbiol 19, 333-355.
Trüper, H. G. \& Pfennig, N. (1981). Isolation of members of the families Chromatiaceae and Chlorobiaceae. In The Prokaryotes: a Handbook on Habitats, Isolation, and Identification of Bacteria, pp. 279-289. Edited by M. P. Starr, H. Stolp, H. G. Trüper, A. Balows \& H. G. Schlegel. Berlin: Springer.

van Niel, C. B. (1944). The culture, general physiology, morphology and classification of the non-sulfur purple and brown bacteria. Bacteriol Rev 8, 1-118. 